\title{
African International Relations, Genocidal Histories and the Emancipatory Project Part 1
}

\author{
H.G. Campbell \\ Syracuse University, Syracuse, USA
}

\begin{abstract}
Silences in the discipline of International Relations on genocide amount to a form of genocide denial, which is one of the foundations of future genocide. The paper posits that in the era of militarized global apartheid, progressive scholars are challenged to critique and expose the past and current crimes against humanity that are occurring in Africa. Drawing from the consolidation of an alternative analysis in the context of the Bandung Project, the paper analyzed the contributions of the ideas that emerged out of the anti-apartheid struggles and the struggles for reparative justice. Struggles from the Global South had culminated in the World Conference against Racism (WCAR) process, elevating the anti-racist battles as a core challenge of Africa's International Relations. This rejuvenation and energies coming out of the protracted struggle for bread, peace and justice took the form of the transition to the African Union leaving behind the concept of the noninterference in the internal affairs of states. The paper analyzed the ways in which afro-pessimism was being reinforced by the constructivist path in African International Relations. The contributions of radical African feminists are presented as one new direction where there is the coalescence of the progressive anti-imperialist intellectual traditions with radical feminisms. These two traditions open possibilities for an emancipatory project. This project has taken on extra importance in the period of the fragility of global capital when the precariousness of capitalism threatens new and endless wars and destabilization in Africa. Modern humanitarianism forms one component of the weaponization of everything and it is within this ensemble of ideas that scholars need to deconstruct the discussion of 'failed states' in Africa.
\end{abstract}

Key words: Bandung Project, Africa, anti-Imperialism, Non-Western IR Theories, genocidal histories, radical feminism, reparative justice, emancipatory project

For citation: Campbell, H.G. (2020). African International Relations, Genocidal Histories and the Emancipatory Project. Part 1. Vestnik RUDN. International Relations, 20 (1), 115-130. DOI: 10.22363/2313-0660-2020-20-1$115-130$

Научная статья

\section{Международные отношения в Африке, истории геноцида и эмансипации \\ Часть 1}

\author{
Х. Кэмпбелл \\ Сиракузский университет, Сиракьюс, США
}

\begin{abstract}
Умолчание проблемы геноцида в международных отношениях — это одна из форм отрицания геноцида, которая в будущем может привести к новым масштабным преступлениям. В статье утверждается, что в эпоху глобального милитаризированного апартеида перед прогрессивными учеными стоит задача критиковать и разоблачать прошлые и нынешние преступления против человечности, которые происходят в Африке. Опираясь
\end{abstract}

(C) Campbell H.G., 2020

This work is licensed under a Creative Commons Attribution 4.0 International License.

https://creativecommons.org/licenses/by/4.0/ 
на альтернативный анализ в рамках Бандунгского проекта, в статье был проанализирован вклад идей, возникших в результате борьбы против апартеида и за репаративное правосудие. Борьба Глобального Юга достигла кульминации в ходе Всемирной конференции против расизма (WCAR), в результате чего антирасистская проблематика стала центральной в международных отношениях в Африке. Новая энергия, появившаяся в результате затяжной борьбы за хлеб, мир и справедливость, приняла форму перехода к Африканскому союзу, оставив позади концепцию невмешательства во внутренние дела государств. В статье анализируется усиление афропессимизма в контексте конструктивистских подходов в африканских международных отношениях. Вклад радикальных африканских феминисток представлен как новое направление, в котором происходит слияние прогрессивных антиимпериалистических интеллектуальных традиций с радикальными формами феминизма. Эти две традиции открывают возможности для эмансипативного проекта. Этот проект приобрел особое значение в период хрупкости глобального капитала, когда неустойчивость капитализма угрожает новыми и бесконечными войнами и дестабилизацией в Африке. Современный гуманизм является оружием против этого, и именно в этом направлении ученые должны вести дискуссию о «несостоявшихся государствах» в Африке.

Ключевые слова: Бандунгский проект, Африка, незападные теории международных отношений, антиимпериализм, геноцид, радикальный феминизм, репаративное правосудие, эмансипативный проект

Для цитирования: Campbell H.G. African International Relations, Genocidal Histories and the Emancipatory Project. Part 1 // Вестник Российского университета дружбы народов. Серия: Международные отношения. 2020. T. 20. № 1. С. 115-130. DOI: 10.22363/2313-0660-2020-20-1-115-130

\section{Introduction}

The teachers of the discipline of International Relations are faced with the stark choice of continuing to downplay genocidal economics embedded in neorealism and neoliberalism or join the worldwide opposition to racial capitalism [Hudson 2017; Robinson 1983] and environmental destruction. After the bloody 20th century, the African people at home and abroad had anchored the Bandung Project and strengthened another branch of the discipline of International Relations that focused on the selfdetermination of colonized persons. The NonAligned Movement that had emerged out of the Bandung Project was fertilized by the global anti-racist struggles so that by the end of the Century, the end of formal apartheid inspired new concepts of social emancipation within the field of International Relations [Prashad 2014; Amin 2006: 169-181]. Radical feminists implicated masculinity and rape as central questions of International Relations enriching international law and the fight against militarism and gender-based violence.

A brand of international relations focusing on the opposing the intersecting oppressions of racism, exploitation of labor, gendered oppression and oppression of peoples of differing sexual orientation emerged slowly by the end of the 20th century [Crenshaw 1989; Steans 2013]. It was the global solidarity against apartheid that sharpened the differences between IR ideas of self-determination of states and the emancipation of people. Out of the solidarity that coalesced from the Mass Democratic Forces and the military defeat of the apartheid state at Cuito Cuanavale $^{1}$ emerged the thrust for reparative justice. Divisions within African intellectuals with respect to the differences between reconciliation and justice were played out in the debates about Ubuntu in South Africa and later in the differences between differing intellectuals over the International Criminal Court (ICC) [Clarke 2019; Agwu 2019].

Pan African scholars who had anchored the opposition to realism in the era of anticolonialism soldiered on with a new emphasis on imperialism in the 21 st century. Samir Amin had expanded on the genocidal potentialities of modern capitalism in his book [Amin 2004]. This study had outlined how globalization had been formulated to blunt opposition to the new tactics of imperialism to intervene through international organs such as the World Trade Organization (WTO), the International Monetary Fund (IMF), and the International Bank for Reconstruction

1 The Battle of Cuito Cuanavale was between August 1987 and March 1988 near the town of Cuito Cuanavale (Angola) between the People's Armed Forces for the Liberation of Angola (FAPLA, the armed wing of the MPLA) and insurgents of the National Union for the Total Independence of Angola (UNITA) supported by South African Army during the Angolan Civil War and South African Border War (Editor's Note). 
and Development (IBRD). African scholars who faced the deleterious impacts of Structural Adjustment Programs (SAPs) were at the forefront of offering alternative interpretations of the current phase of imperialism ${ }^{2}$.

This body of work on Africa could be distinguished from left scholars who were challenging capitalism but completely erased Africa from the discussions on the fragility of contemporary capitalism [Rasmus 2015]. Samir Amin not only challenged the use of the term "marginalization" with respect to the contribution of Africa to the enrichment of the capitalist centers, but also pointed to the importance of delinking from capitalism in an era when monopoly capitalism has reached a new phase [Amin 2014: vii — viii; Amin 2013]. The call for delinking found resonance in the field of International Relations with the publication of texts on the need to decolonize International Relations. There emerged a spate of texts from Africans challenging the theoretical hegemony claimed by scholars from the global North. The authors of edited book, Decolonizing International Relations [Jones 2006], had noted the imperial and male centered nature of the discipline comparing the discipline to that of anthropology, asserting that, "the architects of IR's self-construction not only have ignored the imperial context of the discipline's modem origins but also have self-consciously located IR's heritage or canon in classical European thought from ancient Greece through to the Enlightenment-Thucydides, Machiavelli, Bodin, Grotius, Hobbes, Rousseau, Kant, Hegel, and so on" [Jones 2006].

Within the study of IR in Africa, there have been realists who believed that Africa should decolonize IR, but develop states with real power instead of cooperation. Scholars such as Ali Mazrui had started out as a realist [Mazrui 1977]. After apartheid, Professor Adebajo Adekeye represented himself as a foremost realist arguing whether South Africa or Nigeria should be a

2 African Alternative Framework to Structural Adjustment Programs for Socio Economic Recovery and Transformation (AAF — SAP). Addis Ababa: UNECA, 1989. See also: [Mkandawire, Olukushi 1995]. dominant force in Africa [Adebajo, Adedeji, Landsberg 2007]. Statehood, anarchy, corruption, and the racist concept of "sub Saharan Africa" dominate the curriculum as the imperial realists are now buttressed by Third World Realists [Brown 2006; Dunn, Shaw 2001].

Inside the Third World, neo realism has been dominant in societies such as Brazil and India. In the face of the unilateral projection of power since the end of the Cold War, these scholars from the Brazil, Russia, India, China, and South Africa (BRICS) societies rely largely on the discourse of realist balance of power and geopolitical diplomacy. This kind of realism is also manifest in the body of Chinese scholarship that believes that China should become a super power in the 21st century [Xuetong 2011]. Neoliberalism in economics and neorealism in analyzing the international context dominated the teaching of International Relations in China to the point where the top University (Tsinghua) established a Cecil Rhodes type of leadership training center in alliance with Stephen Schwarzman, Chairman, CEO and Co-Founder of Blackstone, one of the leading investment firms of Wall Street ${ }^{3}$.

Competition between differing factions of global capital, massive technological change in the midst of ecocide, xenophobic ideas, white supremacy, the plunder of human and natural resources in the context of realist scholars pontificating on a "Thucydides Trap" unleashed new forms of warfare across the planet and the weaponization of everything ${ }^{4}$. There has not been enough scholarship on the nature of interdependence in the era of global warming and the urgency of retreating from genocide and genocidal traditions. It is from the Pan African

\footnotetext{
${ }^{3}$ A Cecil Rhodes type program to train future leaders was established by Schwartzman with funding of US \$350million to establish this center in Tsinghua University // Schwartzman Scholars Web-Site. URL: https://www.schwarzmanscholars.org/about/tsinghuauniversity/ (accessed: 10.01.2020).

4 Hudson M. The Weaponization of Economic Theory // Global Research. July 18, 2012. URL: https://michael-hudson.com/2012/07/the-weaponizationof-economic-theory/ (accessed: 10.01.2020). See also: [Brooks 2016].
} 
feminists where there is a rigorous analysis of the implications of genocidal histories [Daley 2008].

Patricia Daley's work on genocidal histories made a modest contribution to the study of African International Relations and was a break from the popularization of genocidal history in states that emerged out of conquest. Of the theories of contemporary IR in the West, realist, constructivist, Marxist and liberal, it was the Marxists and the Feminists who centered mass slaughter and genocidal thinking in IR. Feminists in general, and radical African feminists, in particular, made the essential break with male centered concepts of the State and International Relations that is central to the realist paradigm of failed states [Lintock 1995]. African feminists who start from the position that IR theory has to deal with the dignity of human beings deepened the critique of orthodox IR that had developed by feminists within the discipline of IR. From this body of literature came articles such as "Africa and International Relations" [Nkiwane 2001].

The dramatic interventions of radical women in all parts of Africa, especially Algeria, Egypt, Sudan and Tunisia inspired an urgency on the part of scholars to make a break with the lopsided celebration of "liberation leaders" and the Afro-pessimism implicit in the study of constructivism [Schorr 2011]. At the intellectual level, the philosophy of Ubuntu underlined this emancipatory approach where there was a convergence between the progressive South South position and the radical feminist orientation. Reparative justice, healing and reconstruction are new guides for this emancipatory approach. Kwame Nkrumah had argued that the unification and emancipation of Africa was one of the first steps in the emancipation of humanity [Nkrumah 2007]. The shared values of the struggles for human dignity that informed and inspired the rejection of genocidal violence and constituted one component of the long road ahead for humanization of the African [Agwu 2009].

It is within this context of theoretical contributions from the global struggle for the humanization of the planet that this discussion seeks to locate itself drawing on the development of the paradigm of emancipatory politics. This paradigm builds on the insights of radical feminist scholarship, the struggles for human dignity and the environmentalists such as Wangaari Mathaai ${ }^{5}$ who are struggling for a planet where humans can breathe. Reparative politics and the concept of truth in international relations highlighted the principle of Ubuntu, meaning forgiveness, willingness to share and reconciliation [Campbell 2018]. Michael Neocosmos had echoed the calls of Wamba dia Wamba for emancipatory politics in Africa [Neocosmos 2016]. One limitation of this work was the scant attention paid to genocide and genocidal histories in Africa. The conclusion seeks to grasp the relationship between African unity, new sites for the retraining of leadership and reparations for reconstruction in the era of the information economy. It is here where one will draw from the voices of freedom and the attempts to harness the voices of freedom to unleash the creative potential of the producers in new movements and new organs. The challenge for the new actors will be to transform the African Union to be a union of peoples instead of a union of states.

\section{Context of the Legacies of Genocide Denial}

Even before the end of the "Cold War" there have been systematic efforts to clarify the meaning of the history and legacies of genocidal violence in Africa in order to make a drastic break with the denial of genocide which made genocidal violence continue in Africa. One of the most important aspects of African International Relations has been genocide denial. Gregory Stanton had identified 8 stages of genocide: Classification, Symbolization, Dehumanization, Organization, Polarization, Preparation, Extermination and Denial ${ }^{6}$. The issue of denial is as fundamental as dehumanization or extermination as far as those perpetrators who deny that they committed any crimes, often blame what happened on the victims. Mainstream scholars of International Relations had for over 50 years

${ }^{5}$ Wangaari Mathaai (1940-2011) - Kenyan activist and first African woman to get the Nobel prize (2004 Nobel Peace Prize) (Editor's Note).

${ }^{6}$ Stenton G. The 8 Stages of Genocide // Genocide Watch. 1998. URL: http://genocidewatch.net/2013/03/14/ the-8-stages-of-genocide/ (accessed: 10.01.2020). 
promoted genocide denial. From books on the White Man's burden to the Modernization mantra, the specialists on African IR had seen no contradiction between the genocidal histories and the pacification pogroms in Africa. The hypocrisy was clear in Africa when IR scholars saw no contradiction between the practices of apartheid and the Universal Declaration of Human Rights (UDHR). The apartheid state had been a signatory to the UDHR in 1948.

This hypocrisy was fed into the feedback loop of white supremacy and imperial plunder from the era of colonialism to the current neocolonial phase. Recursive phases of violence and mass killings dotted the landscape throughout the era now written about as the "Cold War". There were hot wars all over Africa. Promoting massive destabilization and destruction was most recently manifest in the machinations and lies that were deployed for the NATO intervention and destruction of Libya. The invasion and destruction of Libya brought to the fore the ways in which theories such as constructivism had matured in the field of International Relations to justify imperial interventions under the banner of humanitarianism and "responsibility to protect" [Campbell 2013; Kuperman 2013]. It is now well established that behind the constructivist norm of humanitarianism was a NATO campaign to empower social forces in Libya that the West had labeled as "terrorists" [Kuperman 2019].

Scholars of African International Relations in Africa had taken the lead to write an Open letter to the United Nations to oppose the carnage in Libya ${ }^{7}$. There are continuing discussions on the "new scramble for Africa" with the 2020 Berlin Conference in Germany ${ }^{8}$, the oppressed peoples of Africa continue to press for the African Union to give concrete meaning to the plans for a united, prosperous and peaceful

${ }^{7}$ Libya: Joint Open Letter: UN Human Rights Council should establish a Commission of Inquiry, or similar mechanism, for Libya // Amnesty International. December 4, 2019. URL: https://www.amnesty.org/en/documents/ mde19/1523/2019/en/ (accessed: 10.01.2020).

8 The Libya conference and the new scramble for Africa // World Socialist Web Site. 18 January 2020. URL: https://www.wsws.org/en/articles/2020/01/18/pers-j18. html (accessed: 10.01.2020).
Africa as articulated in Agenda 2063 ${ }^{9}$. Agenda 2063 had spelt out the goals for the freedom of Africa at a moment when the militarized global apartheid [Besteman 2018] had taken center stage in international politics.

After the defeat of crude apartheid, the constructivist developed a narrative that the end of apartheid had come from the new international norms and ideas that had developed in the "international community" in the aftermath of the "Cold War" [Klotz 1995]. The Bandung Project had strengthened the global antiapartheid struggle that was carried forward by the Mass Democratic Struggles of the liberation movements. These struggles were crystalized with the military defeat of the South African Army at Cuito Cuanavale. North American scholars such as Chester Crocker who had mobilized the academy and the US government to support the South African State under a policy of "Constructive engagement"10 waded in after the military defeat to represent the end of apartheid as the work of "negotiations" and "conflict resolution" specialists from the West who understood that apartheid had to end [Crocker 1992]. Denying the agency of the African peoples in bringing to an end the odious system of apartheid was also evident in the otherwise excellent book by Piero Gleijeses [2013]. Despite the intervention and sacrifices, decolonization was represented as a process where African men and women were not actors in the historical process, but acted upon. Even the language used in many texts about the end of colonization represented Africans as lackluster bystanders.

Since the end of apartheid, there has been very little work in the field of International Relations on the role of the scholars who pushed the neo-liberal turn in the politics of Africa with the World Bank trope of "good governance". Prior to the formal end of apartheid the dominant

9 Agenda 2063: The Africa We Want // African Union. URL: https://au.int/en/agenda2063/overview (accessed: 10.01.2020).

10 "Constructive Engagement" is a policy of the US Reagan administration towards the apartheid regime in South Africa in the early 1980s (Editor's Note). 
ideas of South - South cooperation and a New International Economic Order (NIEO) had informed the thinking of many scholars of African International Relations. In the wake of the reversals for white supremacy in Africa, western foundations, think tanks and governments financed scholars and scholarships with hundreds of millions of dollars to shape concepts of Africa's International Relations [Hearn 2000]. The ideas of Ubuntu and Reconciliation were robbed of their emancipatory content with the new African capitalist class inside the African National Congress (ANC) maintaining that the party is not about revenge, but reconciliation. Reconciliation with capital incorporated the "discourses on democracy and good governance" at the same moment when the political leaders and intellectuals internalized the xenophobia that had been implanted in the society by the apartheid state.

It was the same thinking that induced the South African intellectuals to turn their backs on the Agenda of the World Conference against Racism (WCAR). This third WCAR in September 2001 had emerged from global solidarity between African descendants, the Dalits, Indigenous peoples, Palestinians and the Roma and Sinti peoples. The victory of the declaration that slavery constituted a crime against humanity was buttressed by the Durban Declaration and Program of Action which called for a vigorous education program to bring to the fore genocidal histories ${ }^{11}$.

While the International Relations of Pan African scholarship in Global Africa has produced new texts and the establishment of a Reparations Centre for Research at the University of the West Indies ${ }^{12}$, European diplomats and politicians have been active in Africa, claiming that the enslavement of Africans was perfectly legal and moral. Those Africans whose

11 Durban Declaration and Program of Action (DDPA) // United Nations, Human Rights Council. 2001. URL: https://www.un.org/en/durbanreview2009/pdf/ DDPA_full_text.pdf(accessed: 10.01.2020).

$12 \bar{C}$ entre for Reparation Research. The University of the West Indies. URL: http://www.reparationresearch.org/ (accessed: 10.01.2020). ancestors were complicit in this criminal enterprise argued that the matter was simply a commercial activity.

\section{Constructivism and the Challenges of Genocide in Africa}

Constructivism as one of the contemporary branches of African International Relations had matured in Africa sucking out the energies that had been generated by scholars such as Samir Amin, Amilcar Cabral, Archie Mafeje, Eduardo Mondlane, Walter Rodney, C.L.R. James and Nawal El Sadawi. In fact, in the development of constructivism as one of the branches of postmodernism in African scholarship sought to canonize thinkers such as Frantz Fanon and C.L.R. James in order to denude their work of the anti-imperialist content. It is this contestation that has arisen in the debates on postcoloniality and the relationship to genocidal histories.

Postmodern scholars of International Relations have sought to turn the works of James and Fanon into personal reflections about "racialized subjectivity". In selectively reading Fanon, these scholars have diminished his analysis of genocidal histories and his call for a new human being. In the last Chapter of the Wretched of the Earth [Fanon 1961], Fanon had been explicit about the genocidal traditions of Europe: "We must leave our dreams and abandon our old beliefs and friendships of the time before life began. Let us waste no time in sterile litanies and nauseating mimicry. Leave this Europe where they are never done talking of Man, yet murder men everywhere they find them, at the corner of every one of their own streets, in all the corners of the globe. For centuries they have stifled almost the whole of humanity in the name of a so-called spiritual experience. Look at them today swaying between atomic and spiritual disintegration" [Fanon 1961].

Fanon had explicitly linked anti-black racism to genocide in his analysis of Black Skins White Masks [Fanon 2008]. The body of the work of Fanon interrogated the Lived Experiences of the black person under racism and underlined the necessity to be humanized to transcend racism. This meant that thinkers had to 
develop the theoretical and conceptual tools to be liberated from Eurocentrism and racial essentialism. Karl Marx had grasped this reality at the time of the US Civil War when he wrote: "Labor cannot emancipate itself in the white skin, when in the black it is branded" [Marx 1867/1967: 301].

It was C.L.R. James who had adequately summed up this interconnection between race and liberation when he wrote in the Black Jacobins, that "the race question is subsidiary to the class question, and to think of imperialism in terms of race is disastrous. But to neglect the racial factor as merely incidental, is an error only less grave than to make it fundamental" [James 1989: 283].

Both James and Fanon had implicated the primitive accumulation of capital in the refinement of racist ideas and centralized racism in the development of Europe in the period that is called the era of modernity. For C.L.R. James [1989], what was called modernity was thus a celebration of genocide and genocidal histories. There were many scholars of IR who did not represent the genocide of the Roma peoples in Europe as Genocide. This was the forgotten genocide. Z. Bauman's study on Modernity and the Holocaust [Bauman 1989] broke new ground in exposing the centrality of mass murder in the ideation platform of efficiency, scientific rationality and enlightened humans. Systematized mass murder had been a characteristic of states of conquest and the German capitalists took this systematized murder to the industrial stage.

\section{Genocide, Realism and European "Civilization"}

The dehumanization of the African has been central to the racist past and present of Europe and North America. It is this dehumanization that is at the heart of the genocidal histories of western capitalism. All of the preeminent European capitalist states carried out genocidal violence in the spread of capital. In the scholarly works on Africa, the genocide of ten million Africans in the Congo by the Belgians in the 19th century had been represented as a humanitarian effort [Hochschild 1998]. Belgium as a small state in Europe had embarked on mass killings, torture and scorched earth policies in the
Congo to make a claim for sovereignty in Europe 40 years after its independence in 1830. The Hobbesian ideas of aggressive nationalism, militarism, rival alliances, spheres of influence and economic competition informed and influenced the international relations of Europe in the era of monopoly capitalism 1870-1920 with disastrous results for the rest of humanity. It was in this period where Europe completed the seizure of colonies in all parts of the globe [Rodney 1970]. The 20th century started from the shadows of the violent interventions and genocidal wars in Africa that were called pacification, and these wars paved the way for the traditions of war and genocide of the 20th century. In fact, the genocide of the Herero peoples in Namibia proved to be a dress rehearsal for the Nazi Holocaust.

E.J. Hobsbawm, a prominent Marxist scholar of International Relations called the 20th century, The Age of Extremes and many others noted that this was one of the most violent centuries in human history [Hobsbawm 1996; Shaw 2003]. What Hobsbawm and other students of war failed to do was to connect the specificity of the genocide of the 20th century to Social Darwinism, dehumanization of nonwhites and eugenics. W.E.B. Du Bois had implicated the ideas of white racism in the outbreak of World War I in a little know pamphlet outlined The African Roots of War [Du Bois 1915]. Racism and eugenic thinking in International relations had erased the writings on international relations and African knowledge of the earth that had been documented in the 16th century by travelers and given a 20th century rendition by $\mathrm{Du}$ Bois in The World and Africa An Inquiry Into the Part which Africa Has Played in World History [Du Bois 1947; Smith 2009]. African knowledge of earth and the experiences of African International Relations prior to the era of capitalism have been documented by UNESCO in the General History of Africa $^{13}$, but in the main, this historical foundation of Africa's IR is not well known.

What has been understood in the fields of natural sciences on Africa's contribution to

\footnotetext{
${ }^{13}$ General History of Africa Project // UNESCO. URL: https://en.unesco.org/general-history-africa (accessed: 10.01.2020).
} 
science and mathematics [Eglash 1999] has not yet been grasped in the field of social sciences, so that the ideas of the scientific method influence positivism and the principal methodlogical approaches to the study of International Relations. As a field of intellectual inquiry, the study of International Relations started many centuries ago and Cheikh Anta Diop in his characterization of pre-colonial African States pointed to the nature of state formation in Africa and ancient Greece and the influences on the subsequent theories of International Relations [Diop 1991].

Up to the present the study of precolonial African international relations remains underdeveloped in so far it is the European conception of IR that is reproduced in the text books. There is a difference between the studies of Cheikh Anta Diop and Martin Bernal [1987], on the one hand, and the schools of International Relations that developed in Europe after the First World War. Errol Henderson had critiqued this racism in IR and in studying the relations between states and wrote how "racism was hidden in plain sight in international Relations Theory" [Henderson 2013; Shepherd 1998].

It was in Southern Africa where western capitalism had locked in the system of apartheid to super exploit black labor in the gold mines where the rationale for the semi-slavery conditions was legitimized. Britain and European control of gold was one of the main mechanisms of imperial power in the beginning of the twentieth century and the super exploitation of Black labor in the mines in Southern Africa had been the prop for the international capitalist system [Magubane 1979]. After the carnage of the First World War, the anti-slavery sentiments of the 19th century had been carried forward into the formation of the International Labor Organization (ILO) in the context of the League of Nations.

African scholars such as N.T.A. Nzula had worked hard to bring the questions of forced Labor to the forefront of International Relations, but imperial scholars whether realists or liberals justified colonialism, racism and forced labor in the name of bringing civilization to Africans [Nzula 1979]. All of the colonial states in Africa were propped up by servitude, forced labor, unjust taxation and differentially valuing people's lives and labor setting the stage for the kind of hierarchy of humans that still continues in the 21st century. When the Italians had invaded Abyssinia in 1935, African radicals organized in formations such as the International African Service Bureau and the Council on African Affairs (CAA), opposed Italian fascism and produced a formidable amount of texts on African International Relations that is now relevant in the era of white supremacy [Lynch 1978; Padmore 1969]. The Italian invasion was followed by the Spanish Civil War, the Japanese massacres at Nanjing and the full-blown fascism in Germany under the National Socialists.

\section{German Chauvinism and Genocide in International Law}

Universities in the United States had patterned themselves after European Universities so that forced labor and mass murders had been celebrated as "progress". The experience of the Belgians in the Congo had been replicated by the British in Kenya, by the Portuguese in Angola, by the Germans in Namibia and by the French in all parts of Africa. The Armenian genocide in the early 20th century exposed the linkages between militarism, war and genocidal violence. It was only in 2019 that the French president apologized to the Algerian peoples for the killing of more than one million in the war of independence. These instances of mass murder were not called genocide and it was after the Nazi Holocaust that the concept of genocide entered into the field of International Law.

"The simplest definition of modern genocide is that it is mass murder conceived and perpetrated by modern states and organization" [Gellately, Kiernan 2003].

In the aftermath of the Holocaust, the United Nations adopted the Genocide Convention in $1948^{14}$. The outlines of the UN Convention have

14 The Convention on the Prevention and Punishment of the Crime of Genocide (Genocide Convention) // United Nations. December 9, 1948. URL: https://www.un.org/en/ genocideprevention/genocide-convention.shtml (accessed: 10.01.2020). 
been well documented and contested. The Edited book on The Specter of Genocide [Gellately, Kiernan 2003] goes beyond the empirical data on the genocides committed in the 20th century to analyze the ideation system that justified genocide.

African Americans had intervened at the United Nations in 1948 to bring the charge of genocide against the government of the United States. The famous petition launched by William Z. Patterson, We Charge Genocide [Patterson 1952], was directed to the UN, to demand its inspection and intervention into Jim Crow racism within the USA [Horne 2013]. William Patterson and Paul Robeson had been diplomats of the anti-racist struggles in the aftermath of World War II bringing to the world the reality of genocidal violence beyond Germany.

Writing from the USA where genocide had been represented as "progress" for centuries and popularized in the national consciousness by Hollywood and the film industry, Errol Henderson in his analysis of racism in IR theory had deepened the work of scholars such as Oliver Cox and Cedric Robinson [Henderson 2013]. It was the Pan African rendition of IR theories that inspired the African nationalists such as Kwame Nkrumah and Patrice Lumumba. When Patrice Lumumba rejected the rendition of the realities of the genocide of the peoples of the Congo, he was removed from office and later executed. This form of intervention to justify genocide was also legitimized in the language of anticommunism and Cold War politics [De Witte 2001]. Beth Elise Whitaker and John F. Clark recently represented episodes of western mass murders as aspects of the Cold War [Whitaker, Clark 2018]. Mobutism and the dictatorship of Mobutu Sese Seko became the logical outcome of the destabilization of the Congo. This ensured the remarkable continuity in imperial machine-tions in the Congo from King Leopold II to the present.

One of the more important chapters in King Leopold's Ghost is the final chapter, "The Great Forgetting" that captured the realities of Genocidal histories in Europe [Hochschild 1998]. Hochschild recounted how monuments are built in European cities to forget the history of genocide. Hochschild spelt out the efforts by the Belgian state to celebrate the genocide of Africans in the Congo with the glorification of genocide that is implicit in the Royal Museum of Central Africa in Brussels. Brussels remains the administrative seat of the European Union. Throughout Europe, the traditions of genocide, murders, exploitation and imperial conquest are memorialized as "civilizing missions".

In the main, universities in the United States tended to reproduce the ideation systems of Western Europe in the teaching of International Relations. Henry Kissinger as one of the leading theorists of IR in the USA had famously argued in 1969 that whites were there to stay in Southern Africa, justifying the military, economic and diplomatic support for British, French, Portuguese colonialism and the system of minority white rule. Mainstream U.S. scholars such as Anthony Lake had broken with Henry Kissinger over this policy and wrote a very critical book [Lake 1976]. Other scholars and realists who believed that the Cold War was the most important question for humanity embraced the Tar Baby option and enthusiastically sought to find ways to support the apartheid regime. One such scholar was Chester Crocker who had been an apprentice in the service of Henry Kissinger.

The genocidal traditions of Europe had been internalized in North America and as states of conquest, the European capitalists carried out widespread genocide and enslavement of Africans. According to the scholarship of David Stannard in the American Holocaust, "Before the conquest of the New World the Indian population may have numbered from $8,000,000$ to $110,000,000$; perhaps even $145,000,000$. A moderate population estimate consistent with the latest research is of 55,000,000 Indians. Almost totally as a result of several waves of disease carried to the Americas by the conquering and colonizing Europeans, the Indian population dropped steeply by tens of millions, even possibly by as much as 95 percent. In Mexico alone the Indian population may have fallen by $23,000,000$ to under $2,000,000$. Including those Indians who were killed in warfare and democide, perhaps $60,000,000$ to $80,000,000$ Indians of Central and South 
American and the Caribbean died as 'a result of the European invasion"” [Stannard 1992].

African Scholars and scholars from the First Nation peoples of the world had introduced the importance of reparative justice in the field of International Relations to bring to the fore the traditions of mass killings [Cook-Lynn 2011]. Not only was physical elimination of the indigenous peoples was carried out, but it was popularized by Hollywood. This popularization reinforced on going cultural genocide. "Cultural genocide involved the systematic destruction of traditions, values, language, and other elements which make a one group of people distinct from other groups". Howard Zim in reflecting on physical and cultural genocide in North American scholarship had observed that the easy acceptance of atrocities as deplorable but a necessary price for progress has been rationalized to the point that western societies accept genocide and destruction of other peoples as normal. He noted in his book, A Peoples History of the United States that "one reason these atrocities are still with us is that we have learned to bury them in the mass of other facts, as radioactive wastes are buried in containers in the earth. We have learned to give them exactly the same proportion of attention that teachers and writers often give them in the most respectable of classrooms and textbooks. The learned sense of moral proportion, coming from the apparent objectivity of the scholar, is accepted more easily than when it comes from politicians at press conferences" [Zim 1980].

\section{IR in the Context of the Bandung Project}

When the Egyptians nationalized the Suez Canal in 1956, Gamal Abdel Nasser was putting into practice the call for self-empowerment that had been issued from the Bandung Conference that had been held in Indonesia in 1955. Egypt and Ghana were front and center of this Bandung gathering and out of this emerged another understanding of the need for cooperation in the Global South. Samir Amin had written extensively on the deployment of the Bandung Project in African International Relations [Amin 2006: 169-181]. Vijay Prashad had summed up this project as the struggles for bread, peace and justice by former colonial states. African intellectuals and freedom fighters had adopted this position in order to influence the General Assembly of the United Nations and the Group of 77. It was from this platform that UNCTAD was created and Africans joined the call for a New International Economic Order (NIEO). One of the high points of this international solidarity was laying the foundations for the intervention of the General Assembly of the United Nations and the Human Rights Council [Prashad 2014]. From this activism of African Scholars and diplomats within the international system emanated the Conventions against racism and the labelling of apartheid as a crime against humanity.

The International Convention on the Elimination of All Forms of Racial Discrimination (ICERD) is a United Nations convention. A third-generation human rights instrument, the Convention commits its members "to the elimination of racial discrimination and the promotion of understanding among all races" ${ }^{15}$.

Adopted at the end of the sixties at the height of the Cold War, this Convention blunted the diplomacy of IR scholars in North America and Europe who were active supporters of global racism. It was in this same moment with the energies of the Non-Aligned Movement and the global anti-racist movements that in 1973, the United Nations General Assembly opened for signature and ratification the International Convention on the Suppression and Punishment of the Crime of Apartheid. It defined the crime of apartheid as "inhuman acts committed for the purpose of establishing and maintaining domination by one racial group of persons over any other racial group of persons and systematically oppressing them" 16 .

${ }^{15}$ International Convention on the Elimination of All Forms of Racial Discrimination // United Nations Human Rights. December 21, 1965. URL: https://www.ohchr.org/ en/professionalinterest/pages/cerd.aspx (accessed: 10.01.2020).

16 International Convention on the Suppression and Punishment of the Crime of Apartheid // United Nations. November 30, 1973. URL: https://treaties.un.org/doc/ Publication/UNTS/Volume\%201015/volume-1015-I14861-English.pdf (accessed: 10.01.2020). 
This diplomatic victory was a necessary component of the global anti-apartheid struggles that involved diplomacy, international sanctions, supporting the liberation movements and the mass actions of the oppressed in Southern Africa. All of these four aspects of the global antiapartheid struggles anchored African International Relations within the field of the study of self-determination and inspired a moment of the rejuvenation of African and Pan African scholarship. During April 1994, the peoples of South Africa celebrated the end of apartheid and centuries of institutionalized racism and white supremacy. The promise of a new era of African International Relations was, however, shattered by the news, that same month, of the start of the genocide in Rwanda. Genocidal violence had been rampant in Burundi but the President of Tanzania was thwarted from intervening to stop genocide in Burundi in 1972 when President Michel Micombero argued that he had the legitimate right to kill his own people.

Full scale genocide in Rwanda in 1994 brought the question on nonintervention in the internal affairs of states and issues of sovereignty out from the shadows of the OAU borrowings from conventional international relations theory. War, violence and the avalanche of murders in the Great lakes region of Africa made the traditions of genocide a burning question for the new question of IR that transcended the low respect for human life in Africa. The process of self-determination and self-rule had been inspired by a social movement that wanted a different relationship between the peoples and their governments but in the aftermath of the assassination of Patrice Lumumba in 1961, the Organization of African Unity had been created as a compromise to protect African leaders [Tandon 1972].

Briefly, it can be stated that though the processes of decolonization and independence were inspired by the theories of self-determination, the political leaders had internalized the ideas of territorial integrity and sovereignty of states, instead of conceptions of sovereignty of the people. In so far as centers such as the Nigerian Institute of International Affairs (NIIA) in Lagos and the South African Institute of
International Affairs (SAIIA) were linked organically to similar Institutes in London, Paris, and Washington, the interns on international diplomacy were taught the ideas of Machiavelli, Thomas Hobbes, John Locke, Hans Morgenthau and Henry Kissinger (in short, the ideas of realism). Realists had argued in Europe and the USA that rather than concentrating on disarmament as a route to peace, states and governments should prepare for war in order to maintain balance of power. These ideas were translated into policies that viewed the African military as vehicles for modernization and stabilization. Lucien Pye's writings on the Military and modernization were very influential in this period [Pye 1971].

It was in Dar es Salaam, Tanzania where there were efforts to introduce the theories of Amilcar Cabral, Samora Machel, Kwame Nkrumah and the thinking that informed the liberation process. The Mozambique-Tanzania Centre for Foreign Relations (CFR) ${ }^{17}$, as a higher learning institution in Dar es Salaam, Tanzania did not teach the writings of Thucydides, that "the strong do what they can, the weak suffer what they must". As one of the designated least developed States, the political leadership of Tanzania under Julius Nyerere opposed genocide and the Tanzanian candidate for the Secretary General of the United Nations, Salim Ahmed Salim exposed the possibilities of principled diplomats from the Global South.

It was in this environment of national liberation where Marxism as an alternative explanatory tool emerged within the teaching of African International Relations. However, as the publications of the Dar es Salaam debates showed, there was a crude and mechanistic application of Marxism that did not break from the determinism of classical Marxist thought [Tandon 1982; Tandon 1984]. In states such as Egypt, Sudan, Nigeria and Ethiopia there were Marxist scholars who attempted to carve out alternative spaces for intellectual reproduction but the savagery of the repression of the Cold War killed many scholars and drove hundreds

${ }^{17}$ Center for Foreign Relations official website. URL: https://cfr.ac.tz/ (accessed: 10.01.2020). 
into exile. Nigerian Marxists had come in for special opprobrium with international capital going overboard to coopt and exploit the stillborn Nigerian Socialist movement [Mayer 2016]. Most of the leaders of the liberations movements such as Amilcar Cabral, Agostino Neto, Mario Andrade, Deolinda Rodrigues, Samora Machel, Marcelino Dos Santos, Aquino de Braganza, Robert Mugabe, Chris Hani, Joe Slovo and Ruth First had adhered to some variant of Marxist thought. Of the eleven thinkers named above, five lost their lives as imperialism sought to crush ideas of African freedom. Those South African Marxists who had survived because of exile returned after 1994 but were no match for the millions of dollars being spent to entrench neo liberalism and post modernity into the South African academy.

By the time of the fall of the Berlin Wall in 1989, the Marxist methodology had been vigorously debated in Africa and the philosophical explorations that were inspired by the end of apartheid brought to the fore ideas of the African Renaissance and Ubuntu. Even with the debates on the African Renaissance, the intellectual subservience the ideas of the stages of human development were very clear in the Thabo Mbeki's rendition of African Renaissance. It was thus not accidental that neoliberal projects such as the New Partnership for Africa's Development (NEPAD) were developed within the intellectual traditions of the World Bank prescriptions for Africa. Patrick Bond had captured the duplicity implicit in the neoliberal proposals of NEPAD [Bond 2004].

Within the discipline of African International Relations, there have been conferences and meetings grappling with the question of the relationship between the epistemological frameworks and easy justification of genocide and mass murder. This has taken the form of a critical assessment of the methodologies used in the teaching of contemporary International Relations theory. However, the traditions of realism and positivism have such a firm root within the University as neo colonial capitalism has a firm root in the body politic that there is still equivocation over the issues of the realities of genocidal histories in Africa. This kind of equivocation is best expressed in books such as International Theory: Positivism and Beyond [Smith, Booth, Zalewski 1996]. The search for alternative paradigms beyond positivism has taken many forms and found expression in the publications of African scholars in organizations such as the African Association of Political Scientists (AAPS) and the Council for the Development of Social Science Research in Africa (CODESRIA) [Mafeje 1992].

Mahmood Mamdani sought to explore the implications of the realist ideas of citizenship in his book, Citizens and Subjects: Contemporary Africa and the Legacy of Late Colonialism [Mamdani 1996]. As one of the participants of the Marxist debates of the seventies, Mamdani was aware of the importance of academic work in the area of policy making. His intervention in the book, When Victims Become Killers: Colonialism, Nativism, and the Genocide in Rwanda complicated the questions raised by the media discourse on the origins of the Rwanda genocide [Mamdani 2002]. Michael Barnett in his work on Eyewitness to a Genocide: The United Nations and Rwanda had attributed the failure to act as a result of the "Bureaucratic Infrastructure of Indifference" [Barnett 2002]. The conception of indifference was never related to genocidal histories in Central Africa, nor the complicity of the French state and mainstream intellectuals in France who orchestrated French support of the ruling Hutu Habyarimana regime, Belgian supply of arms, as well as the humanitarian aid these nations proffered. Phillip Gourevitch in his study of the Rwanda Genocide determined that the non-intervention by the USA and the United Nations was a success in so far as the USA did not see intervention in the national interest of the USA [Gourevitch 1999]. General Romeo Dallaire, the former force commander of the UN mission to Rwanda in 1993-1994 determined that the Rwanda genocide was the Failure of Humanity [Dallaire 2004].

However, there has been some attention to the violence perpetrated by women with the participation of women as killers described as "unprecedented anywhere in the world". The presence of "female génocidaires", exposed the power of propaganda in mobilizing even 
oppressed women to participate in genocidal violence [Jones 2002]. The realities of this genocide have been so massive that many social scientists have steered clear of the subject and novelists represent these violent genocidal experiences as acts of evil [Diop 2014]. More recently, some scholars have resorted to the Kantian concept of Radical Evil to be able to grasp war crimes and crimes against humanity in Africa [Agwu 2019]. Professor Agwu in his book on the ICC implored the African Union to remain in the ICC when leaders in countries such as Kenya and the Sudan had tapped into African nationalism to argue that the International Criminal Court is illegitimate because it was targeting Africans. This author had waded in to argue that Pan Africanists from the grassroots cannot await the legal processes of the International Criminal Court (ICC) to organize against criminality and genocide in Africa.

Scholars of International Relations were critiqued for not exposing the post-election violence of Kenya in 2008 where political leaders had mobilized the African Union to withdraw support for the ICC. Scholars will have to take the lead to ensure that those who commit genocidal violence and crimes against humanity are tried in the court of public opinion and isolated in every way. In this way all of the resources available within the Pan African Movement must be deployed to ensure that the members of criminal syndicates involved in drug running, gun running and money laundering cannot use these resources to corrupt the political processes.

Mahmoud Mamdani argued that, "there is no doubt that the perpetrators of violence should be held accountable, but when and how is a political decision that cannot belong to the ICC prosecutor. More than the innocence or guilt of the president of Sudan, it is the relationship between law and politics, including the politicization of the ICC, which poses a wider issue, one of greatest concern to African governments and peoples" [Mamdani 2010: 273].

Feminists have enriched the research on genocide liberating the study from its male centered preoccupations. These scholars have researched the reality that systemic gender persecution and violence against women "do not constitute a crisis for international lawyers" [Starr 2007]. Ifi Amadiume in her scholarship not only introduced new conceptions of gender but also explored the relationship between The Politics of Memory: Truth, Healing and Social Justice [Amadiume, An-Na'im 2000].

Received / Поступила в редакцию: 28.01.2020

Accepted / Принята к публикации: 10.03.2020

\section{References / Библиографический список}

Adebajo, A., Adedeji, A. \& Landsberg, C. (2007). South Africa in Africa: The Post-Apartheid Era. Scottsville: University of KwaZulu-Natal Press.

Agwu, F.A. (2009). National Interest, International Law and Our Shared Destiny. Ibadan: Spectrum Books.

Agwu, F.A. (2019). Africa and International Criminal Justice: Radical Evils and the International Criminal Court. London: Taylor and Francis. DOI: 10.4324/9780429342738

Amadiume, I. \& An-Na'im, A.A. (2000). The Politics of Memory: Truth, Healing and Social Justice. London: Zed Books.

Amin, S. (2004). The Liberal Virus: Permanent War and the Americanization of the World. New York: Monthly Review Press.

Amin, S. (2006). A Life Looking Forward: Memoirs of an Independent Marxist. London: Zed Books.

Amin, S. (2013). The Implosion of Contemporary Capitalism. New York: Monthly Review Press.

Amin, S. (2014). Capitalism in the Age of Globalization. London: Zed Press.

Barnett, M. (2002). Eyewitness to a Genocide: The United Nations and Rwanda. New York: Cornell University.

Bauman, Z. (1989). Modernity and the Holocaust. New York: Cornell University Press.

Bernal, M. (1987). Black Athena: Afroasiatic Roots of Classical Civilization. Vol. I: The Fabrication of Ancient Greece, 1785-1985. New Brunswick: Rutgers University Press.

Besteman, C. (2018). Militarized Global Apartheid. Current Anthropology, 60 (19), 26-38. DOI: 10.1086/699280 
Bond, P. (2004). Talk Left, Walk Right: South Africa's Frustrated Global Reforms. Scottsville: University of KwaZulu-Natal Press.

Brooks, R. (2016). How Everything Became War and the Military Became Everything. New York: Simon \& Schuster.

Brown, W. (2006). Africa and International Relations: A Comment on IR Theory, Anarchy and Statehood. Review of International Studies, 32 (01), 119-143. DOI: 10.1017/S0260210506006954

Campbell, H. (2018). Nelson Mandela and the Universalist Spirit. In: Shubin, V.G. \& Zelenova, D.A. (Eds). South Africa: Pages of History and Contemporary Politics. Moscow: Institute for African Studies, Russian Academy of Sciences.

Campbell, H.G. (2013). Global NATO and the Catastrophic Failure in Libya: Lessons for Africa in the Forging of African Unity. New York: Monthly Review Press.

Clarke, K.M. (2019). Affective Justice: The International Criminal Court and the Pan-Africanist Pushback. Durham: Duke University Press.

Cook-Lynn, E. (2011). A Separate Country: Postcoloniality and American Indian Nations. Lubbock: Texas Tech University Press.

Crenshaw, K. (1989). Demarginalizing the Intersection of Race and Sex: A Black Feminist Critique of Antidiscrimination Doctrine, Feminist Theory and Antiracist Politics. University of Chicago Legal Forum, 1, 139-167. URL: https://chicagounbound.uchicago.edu/cgi/viewcontent.cgi?referer=\&httpsredir=1\&article= 1052\&context $=$ uclf (accessed: 10.01.2020).

Crocker, C. (1992). High Noon in Southern Africa: Making Peace in a Rough Neighborhood. New York: Norton.

Daley, P. (2008). Gender and Genocide in Burundi: The Search for Spaces of Peace in the Great Lakes Region. London: James Currey.

Dallaire, R. (2004). Shake Hands with the Devil. The Failure of Humanity. New York: Carroll and Graf Publishers.

De Witte, L. (2001). The Assassination of Lumumba. New York: Verso Books.

Diop, B.B. (2014). Murambi, le livre des ossements. Paris: Zulma Editions.

Diop, C.A. (1991). Civilization or Barbarism: An Authentic Anthropology. New York: Lawrence Hill.

$\mathrm{Du}$ Bois, W.E.B. (1915). The African Roots of War. Atlantic, May, 707-714. URL: $\mathrm{http} / / /$ scua.library.umass.edu/digital/dubois/WarRoots.pdf (accessed: 10.01.2020).

Du Bois, W.E.B. (1947). The World and Africa: An Inquiry into the Part Which Africa Has Played in World History. New York: Viking Press.

Dunn, K.C. \& Shaw T.M. (Eds). (2001). Africa's Challenge to International Relations Theory. New York: Palgrave.

Eglash, R. (1999). African Fractals: Modern Computing and Indigenous Design. New Brunswick: Rutgers University Press.

Fanon, F. (1961). The Wretched of the Earth. New York: Grove Press.

Fanon, F. (2008). Black Skin, White Masks. New York: Grove Press.

Gellately, R. \& Kiernan, B. (2003). The Specter of Genocide: Mass Murder in Historical Perspective. Cambridge: Cambridge University Press. DOI: 10.1017/CBO9780511819674

Gleijeses, P. (2013). Visions of Freedom: Havana, Washington, Pretoria, and the Struggle for Southern Africa, 1976 - 1991. Chapel Hill: University of North Carolina Press.

Gourevitch, P. (1999). We Wish to Inform You That Tomorrow We Will Be Killed with Our Families: Stories from Rwanda. New York: Picador Books.

Hearn, J. (2000). Aiding Democracy? Donors and Civil Society in South Africa. Third World Quarterly, 21 (05), 815-830. DOI: $10.1080 / 713701079$

Henderson, E.A. (2013). Hidden in Plain Sight: Racism in International Relations Theory. Cambridge Review of International Affairs, 26 (01), 71-92. DOI: 10.1080/09557571.2012.710585

ways that support the vThe Age of Extremes: A Short History of the World. New York: Vintage Books.

Hochschild, A. (1998). King Leopold's Ghost: A Story of Greed, Terror and Heroism in Colonial Africa. New York: Mariner Books.

Horne, G. (2013). Black Revolutionary: William Patterson and the Globalization of the African American Freedom Struggle. Champaign: University of Illinois Press.

Hudson, P.J. (2017). Racial Capitalism and the Dark Proletariat. Boston Review, Winter. URL: http://bostonreview.net/forum/remake-world-slavery-racial-capitalism-and-justice/peter-james-hudson-racialcapitalism-and (accessed: 10.01.2020).

James, C.L.R. (1989). The Black Jacobins: Toussaint L'Ouverture and the San Domingo Revolution. New York: Vintage Books. 
Jones, A. (2002). Gender and Genocide in Rwanda. Journal of Genocide Research, 4 (01), 65-94. DOI: $10.1080 / 14623520120113900$

Jones, G.B. (Eds.). (2006). Decolonizing International Relations. Lanham: Rowman and Littlefield.

Klotz, A. (1995). Norms Reconstituting Interests: Global Racial Equality and U.S. Sanctions against South Africa. International Organization, 49 (03), 451 - 478. DOI: 10.1017/S0020818300033348

Kuperman, A.J. (2013). A Model Humanitarian Intervention? Reassessing NATO's Libya Campaign. International Security, 38 (01), 105-136. DOI: 10.1162/ISEC_a_00126

Kuperman, A.J. (2019). America's Little-Known Mission to Support Al Qaeda's Role in Libya. National Interest, August 13. URL: https://nationalinterest.org/feature/americas-little-known-mission-support-al-qaedas-rolelibya-73271 (accessed: 10.01.2020).

Lake, A. (1976). The "Tar Baby" Option: American Policy toward Southern Rhodesia. New York: Columbia University Press.

Lintock, A. (1995). Imperial Leather: Race Gender and Sexuality in the Colonial Context. London: Routledge.

Lynch, H.R. (1978). Black American Radicals and the Liberation of Africa: The Council on African Affairs, 19371955. New York: Cornell University.

Mafeje, A. (1992). In Search of an Alternative: A Collection of Essays on Revolutionary Theory and Politics. Harare: SAPES Books.

Magubane, B.M. (1979). The Political Economy of Race and Class in South Africa. New York: Monthly Review Press.

Mamdani, M. (1996). Citizen and Subject: Contemporary Africa and the Legacy of Late Colonialism. Princeton: Princeton University Press.

Mamdani, M. (2002). When Victims Become Killers: Colonialism, Nativism, and the Genocide in Rwanda. Princeton: Princeton University Press.

Mamdani, M. (2010). Saviors and Survivors: Darfur, Politics, and the War on Terror. New York: Doubleday.

Marx, K. (1867/1967). Capital. New York: International Publishers.

Mayer, A. (2016). Naija Marxisms: Revolutionary Thought in Nigeria. London: Pluto Press.

Mazrui, A. (1977). Africa's International Relations: The Diplomacy of Dependency and Change. Boulder: Westview Press.

Mkandawire, T. \& Olukushi, A. (Eds.) (1995). Between Liberalisation and Oppression: The Politics of Structural Adjustment in Africa. Dakar: CODESRIA.

Neocosmos, M. (2016). Thinking Freedom in Africa: Toward a Theory of Emancipatory Politics. Johannesburg: Wits University Press.

Nkiwane, T. (2001). Africa and International Relations: Regional Lessons for a Global Discourse. International Political Science Review, 22 (03), 279-290. DOI: 10.1177/0192512101223005

Nkrumah, K. (2007). Africa Must Unite. London: Panaf Books.

Nzula, A.T. (1979). Forced Labour in Colonial Africa. Chicago: Lawrence Hill Books.

Padmore, G. (1969). How Britain Rules Africa. New York: Negro Universities Press.

Patterson, W.L. (1952). We Charge Genocide: The Historic Petition to the United Nations for Relief from a Crime of the United States Government Against the Negro People. Detroit: Civil Rights Congress.

Prashad, V. (2014). The Poorer Nations: A Possible History of the Global South. New York: Verso Books.

Pye, L. (1971). Warlord Politics: Conflict and Coalition in the Modernization of Republican China. New York: Praeger.

Rasmus, J. (2015). Systemic Fragility in the Global Economy. Atlanta: Clarity Press.

Robinson, C. (1983), Black Marxism: The Making of the Black Radical Tradition. Chapel Hill: University of North Carolina Press.

Rodney, W. (1970). The Imperialist Partitioning of Africa. Monthly Review, 21 (11), 103-114.

Schorr, V. (2011). Economics of Afro-Pessimism: The Economics of Perception in African Foreign Direct Investment. Nokoko, 2, 23-62.

Shaw, M. (2003). War and Genocide: Organized Killing in Modern Society. Oxford: Polity Press.

Shepherd, G.W. (1998). The Study of Race in American Foreign Policy and International Relations. In: Krenn, M. (Eds.). Race and U.S. Foreign Policy from Colonial Times through the Age of Jackson. New York: Garland Publishers.

Smith, K. (2009). Has Africa Got Anything to Say? African Contributions to the Theoretical Development of International Relations. The Round Table, 98 (402), 269-284. DOI: 10.1080/00358530902895378

Smith, S., Booth, K. \& Zalewski, M. (Eds). (1996). International Theory: Positivism and Beyond. Cambridge: Cambridge University Press. 
Stannard, D. (1992). The American Holocaust: Columbus and the Conquest of the New World. Oxford: Oxford University Press.

Starr, S. (2007). Extraordinary Crimes at Ordinary Times International Justice beyond Crisis Situations. Northwestern University Law Review, 101 (03), 1257-1314.

Steans, J. (2013). Gender and International Relations. Oxford: Polity Books.

Tandon, Y. (1972). The Organization of African Unity: A Forum for African International Relations. The Round Table, 62 (246), 221-230. DOI: 10.1080/00358537208453021

Tandon, Y. (1982). University of Dar es Salaam: Debate on Class, State and Imperialism. Dar es Salaam: Tanzania Publishing House.

Tandon, Y. (1984). Arguments within African Marxism: the Dar es Salaam Debates. Journal of African Marxists, 5 , $31-43$.

Whitaker, B.E. \& Clark, J.F. (2018). Africa's International Relations, Balancing Domestic and Global Interests. Boulder: Lynne Rienner.

Xuetong, Y. (2011). Ancient Chinese Thought, Modern Chinese Power. Princeton: Princeton University Press.

Zim, H. (1980). A People's History of the United States. New York: Harper \& Row.

About the author: Campbell Horace G. - PhD, Professor of Political Science and African American Studies, Maxwell School of Citizenship and Public Affairs, Syracuse University, New York, USA (e-mail: hgcampbe@syr.edu).

Сведения об авторе: Кэмпбэл Хорас - доктор философии, профессор политологии и афро-американских исследований, Школа гражданства и публичной политики им. Дж. Максвелла, Сиракузский университет, Нью-Йорк, США (e-mail: hgcampbe@syr.edu). 